\title{
BELIEFS ABOUT OBJECTS
}

\author{
L. S. CARRIER
}

University of Miami

I

Sentences expressing one's beliefs provide a paradigm for contexts that are opaque. ${ }^{1}$ An opaque context is one in which it is unclear what sort of relationship between objects, if any, is being expressed. For instance, Mr. Holmes may believe that a redheaded man is leering at him from a doorway, but he may not believe that a man with a pegleg is leering at him, because the redheaded, peglegged man might be doing his leering from behind a Dutch door the lower half of which is shut. To what individual, it may now be asked, is Holmes related through his belief? "To the redheaded man in the doorway," one is tempted to reply. But he is identical with the peglegged man to whom Holmes is not related through belief. So if we want to say what Holmes's belief was about, we seem forced to say that it was about an impossible object, since it is an object both believed and not believed by Holmes to have been leering at him. But such a result is intolerable. There are no impossible objects. This consideration alone has led some philosophers to conclude that our beliefs cannot be about objects at all when the sentences expressing such beliefs are opaque. ${ }^{2}$ I hope to show, however, that this con-

1 The term "opaque" is borrowed from W. V. O. Word and Object (M. I. T. and New York, 1960), pp. 141-156. Quine speaks of "referential opacity," but since I think it unnecessary to get entangled among various theories of reference here, I prefer to avoid any mention of the speech act or referring.

2 This is Quine's position; ibid., p. 145. 
clusion is premature and that a better answer can be given to such puzzles concerning belief sentences.

We should first get more clearly in mind how it is that opaque contexts are generated. Let us say that a sentence $\mathrm{S}$ is opaque, if, by substituting for a term $t$ in $S$ another term $t^{\prime}$ that applies to the same thing(s), the resultant sentence $S$ ' may come to have a different truth value. ${ }^{3}$ This condition makes it clear that belief sentences fall within the wider class of opaque sentences that describe what Russell called "propositional attitudes." Sentences in which such verbs as "wishes," "hopes," "fears," "knows," and "perceives" precede a propositional clause are among those which may also generate opaque contexts. What I shall later say about the construction of appropiate predicates for opaque belief sentences is meant to apply mutatis mutandis to sentences expressing these other attitudes. There still remains, however, a logical difference between belief and these other attitudes, and I shall catalogue this difference before I am done.

\section{II}

My initial aim is to show that the mere opacity of a belief sentence provides no reason for denying that a relation can exist between a subject and an object that the subject believes to have some characteristic. But this claim seems to be at odds with the principle that is called upon to sanction the substitution of identities in non-opaque contexts, a principle usually called "Leibniz's Law." Properly interpreted, this principle can be expressed as follows:

Leibniz's Law. If any two terms " $\mathrm{x}$ " and " $\mathrm{y}$ " designate the same object, then what is true of $x$ is true of $y$, and conversely.

Faced with opaque contexts one might be tempted to

3 Cf. Quine for a similar analysis; ibid., p. 151. 
argue that Leibniz's Law fails and must therefore be restricted to contexts that are not opaque. But I propose that we avoid this common tactic by applying Leibniz's Law with different presuppositions. Although it is customary to assume that perdicates contained in opaque sentences are to be interpreted like predicates in non-opaque sentences, we can salvage Leibniz's Law in opaque contexts by interpreting our predicates differently. Let me now clarify this.

In a non-opaque sentence like "Xenophon kicked Yardley" the predicate which we take to be true of Xenophon is the predicate "kicked Yardley"; and the predicate true of Yardley is "was kicked by Xenophon." Under this normal construction of predicates Leibniz's Law can easily be seen to hold when codesignative terms are substituted for either "Xenophon" or "Yardley." But consider the opaque sentence "Arthur believes that Cicero was bald." In saying that the sentence is opaque we have already agreed that the following sentences might all be true together:

(1) Arthur believes that Cicero was bald.

(2) Arthur does not believe that Tully was bald.

(3) Cicero is the same as Tully.

If we now assume that predicates for apaque sentences are to be constructed in the same way as they are for nonopaque sentences, we must say that (1) entails:

(4) The predicate "is believed by Arthur to have been bald" is true of Cicero.

But then for the same reasons we must also say that (2) entails:

(5) The predicate "is not believed by Arthur to have been bald" is true of Tully.

Now it is impossible for one and the same individual to have contradictory predicates true of him at the same time. 
But this is exactly what the conjuction of the sentences (3), (4), and (5) comes to. So if we apply Leibniz's Law while interpreting our predicates in the customary way, then we have contradicted our hypothesis that $(1),(2)$, and (3) can all be true together. Hence either Leibniz's Law fails, or the predicates involved must be constructed differently. Although it has been widely assumed that Leibniz's Law fails, we can now see that this is not our only choice. We can also escape contradiction by viewing our predicates in a new way. Let me now suggest how we can do this.

\section{III}

My proposal is that predicates in belief sentences be constructed to include mention of the meaning of the term which designates the object of one's belief. ${ }^{*}$ Perhaps this already sounds too bold. It might be thought a boon to one's ontology if one could, instead of mentioning meanings of linguistic designations, just get by with mentioning the linguistic designations alone. This suggestion was made with some trepidation by Leonard Linsky $;^{5}$ and it would transform our belief-predicate sentences (4) and (5) into, respectively:

(6) The predicate "is believed by Arthur to have been bald under the term "Cicero"' is true of Cicero.

(7) The predicate "is not believed by Arthur to have been bald under the term 'Tully'" is true of Tully.

Although this suggestion would enable Leibniz's Law to escape unscathed in opaque contexts, it has what appears to be an insuperable difficulty. If we assume that Arthur's language does not have the words "Cicero" and "Tully"

4 This approach is not new. P. T. Geach attributes basically the same idea to the medieval logician John Buridan; "A Medieval Discussion of Intentionality", in Y. Bar-Hillel (ed.), Logic, Methodology and the Philosophy of Science (Amsterdam, 1965), pp. 425-433.

5 Leonard Linsky, Referring (London, 1967), pp. 113-114. 
in it, but instead has words that serve as translations of them, then (6) and (7) would be false, while (1) and (2) might still be true. In order to insure the truth of (6) and (7), we need to specify further that Arthur's belief holds under the English word "Cicero" and that his lack of belief obtains under the English word "Tully." But if we include a specific reference to English terms in (6) and (7), it seems as if these can no longer serve as translations of (1) and (2), since the latter make no reference to any language at all. So the mention of linguistic designations, with their required reference to the language that contains them, just will not do.

But the mere mention of meaning itself will not do, either, since there is good reason to think that truth might not be saved in belief sentences even if the substituted term has the same meaning as the term it replaces. This point was first urged by Benson Mates, ${ }^{7}$ whose argument can be reconstructed as follows. If any two terms in English have the same meaning, then the terms "Greeks" and "Hellenes" do. But if we substitute term "Hellenes" for the last occurrence of the term "Greeks" in the following sentence, then what results is doubtful:

(8) Whoever believes that Greeks are Greeks believes that Greeks are Greeks.

This means that the following sentence is false:

(9) Nobody doubts that whoever believes that Greeks are Greeks believes that Greeks are Hellenes.

But since (8) is a sentence nobody doubts, the following is true:

B A form of this translation argument was used effectively against Carnap's view that belief was a relation between a person and a sentence by $A$. Church, "On Carnap's Analysis of Statements of Assertion and Belief", Analysis, 10 (1950), pp. 97.99.

7 Benson Mates, "Synonymity", University of California Publications in Philosophy, 25 (1950), pp. 201-226. 
(10) Nobody doubts that whoever believes that Greeks are Greeks believes that Greeks are Greeks.

If we now take (10) to be the sentence in which we substitute "Hellenes" for "Greeks" and take (9) to be the result of such substitution, we see that even when two terms have the same meaning, the substitution of one for the other can fail to preserve truth.

To get around these difficulties I shall appeal to the notion of partial meaning, as opposed to that of complete meaning. Since it would take me too far afield to analyze both these notions in detail, suffice it to say that, if what we normally call "the meaning" of an expression is taken to be its complete meaning, then the partial meaning of a term will be that part of its complete meaning grasped by the person whose belief is being considered. This allows us to say that two terms may have the same complete meaning, even though their partial meanings are different. By appealing to a difference in partial meanings, we can account for the possibility that even the substitution in a belief sentence of one term for another with the same complete meaning can lead to a change in truth value. ${ }^{8}$.

We can now insure that Leibniz's Law holds in opaque contexts by constructing predicates that mention partial meanings. Instead of (4) and (5) we now have:

(4a) The predicate "is believed by Arthur to have been bald under Arthur's meaning for "Cicero'" is true of Cicero.

(5a) The predicate "is not believed by Arthur to have been bald under Arthur's meaning for 'Tully'" is true of Tully.

8 It should not be thought that speaking of partial meanings commits one to irreducible meaning entities. One can remain neutral on this point. I have even argued that talk about meanings can be analyzed in terms of how one can identify that of which one speaks, in "Meaning and Proper Names", Southern Journal of Philosophy, 9 (1971), pp. 237-245. 
Since (4a) and (5a) mention different predicates, we are not forced to say that one and the same individual, Cicero (that is, Tully), has contradictory predicates true of him at the same time. This constitutes a major step toward showing that mere opacity need not destroy a belief-relation between a person and the object that his belief concerns. Opaque sentences do not force us to attribute contradictory predicates to the same entity, because we can now distinguish between failure of substitutivity, the mark of opacity, and Leibniz's Law, the logical principle that insures that whatever is true of an object remains true of it no matter how this object is designated or described. Substitution of identities may fail in belief contexts, but Leibniz's Law, given predicates like those in (4a) and (5a), continues to hold.

Generally speaking, in any opaque belief sentence, what is true of any object $O$, believed by $A$ to have property $P$, is a certain complex predicate, namely, "is believed by $\mathrm{A}$ to be $P$ under A's meaning for ' $O$ '." I take this sort of complexity to be logical, and not merely grammatical. For instance, we can easily turn this predicate into a relational expression by excising the first occurrence of the singular term " $\mathrm{A}$ "; what then remains is a two-place predicate true of the ordered pair $O$ and $A$. The predicate may be made still more complex by making explicit the further assumption that when A's belief that $O$ has $P$ is expressed in an opaque sentence, then this belief is held under A's meaning for both "O" and "P." I am not concerned here, however, with the final logical unpacking of the belief relation. Suffice it to say that what a person learns when he comes to understand belief sentences is a general rule for operating with the meanings of the singular and general terms under which these beliefs are held.

It should also be emphasized that the word "object" is to be taken seriously here, as it is to be taken in its ocurrence in Leibniz's Law. It will not do to replace the 
term "O" with a description like "the round square," or any name for a so-called "impossible object." Leibniz's Law only applies to that which can have predicates true of it, and this cannot be so with impossible objects which are, by definition, no objects at all. In similar fashion Leibniz's Law does not apply to what is fictitious, such as what one purports to designate by the names "Cerberus" and "Jove." Strictly speaking, this is another case in which there is no object of which a predicate is true. Where there is no object for one's belief to be about, as in one's fancies, we can conveniently treat such a belief as being simply a state of the person holding it, and not any relation at all.

\section{IV}

Though belief sentences can be opaque, they are not necessarily so. We can also interpret a sentence of the form "A believes that $\mathrm{O}$ is $\mathrm{P}$ " to mean: "Some object is believed by $A$ to be $P$, and this object just happens to be called ' $O$ '." It is common to call this a transparent interpretation of the belief context, since we are meant to assume that substitution of identities will preserve truth. Leibniz's Law holds good here without recourse to complex predicates, because no dependence upon the way in which objects just happen to be specified is thought to make a difference to the truth value. Once we agree to a transparent interpretation we must also agree that the belief just concerns the object, regardless of the guise in which it appears; that is, regardless of the partial meaning the believer has for the term designating the object that his belief concerns.

According to Quine, the transparent sense of belief is not to be dismissed lightly, but he goes on to say:

Yet let its urgency not blind us to its oddity. "Tully,"

Tom insists, "did not denounce Catiline. Cicero did." Surely Tom must be acknowledged to believe, in every sense, that Tully did not denounce Catiline and that 
Cicero did. But he must be said also to believe in the referentially transparent sense, that Tully did denounce Catiline. The oddity of the transparent sense of belief is that it has Tom believing that Tully did and that he did not denounce Catiline.

In the light of the previous discussion, Quine's point might be better put by saying, not that the transparent sense of belief is odd, but that we cannot, upon pain of landing Tom with contrary beliefs, interpret both the sentence "Tom believes that Cicero denounced Catiline" and the sentence "Tom believes that Tully did not denounce Catiline" transparently at the same time. Tom's insistent, "Tully did not denounce Catiline. Cicero did," provides a situation in which we are at a loss to say which belief sentence ought to be translated in the transparent way. Quine himself suggests the proper solution: we must interpret Tom's belief in the opaque way. ${ }^{10}$

Quine's criticism of the transparent sense of belief affects only those who think that transparent interpretations can always be given. I take his point to be that the circunstances will dictate whether a transparent or an opaque interpretation is needed. Whenever we have reports of conflicting beliefs, and we do not know which of them to discount, there is nothing left to do but to give an opaque interpretation if we want to make sense of what someone believes. On this basis, however, Quine proceeds to argue that opacity cannot be combined with quantification in certain crucial ways; for such combination requires definite objects to serve as values of the variables, and opaque contexts do not yield such definite objects. But it is here that I disagree, since I think that opacity and objecthood are not incompatible at all; and if there is some difficulty involved in quan-

9uine, op. cit., p. 148.

10 Ibid., p. 149. 
tifying into opaque contexts, it is not a difficulty that Quine's argument reveals.

\section{V}

Quine's argument against quantifying into an opaque context seems to come only to this." Suppose we interpret a sentence of the form "A believes that $O$ is $P$ " opaquely. This means that a sentence for the form "A does not believe that $\mathrm{U}$ is $\mathrm{P}$ " might also be true, even though the terms " $O$ " and " $U$ " designate the same object. But quantification requires that variables range over definite individuals, and, in the case imagined, who could this individual be? Quine cannot make sense of a quantified sentence like "There is an $x$ such that A believes that $x$ is $P$," when A's belief is interpreted opaquely. But this seems to be because he thinks that it forces us to admit that a value of a variable could have contradictory predicates true of it. Since it is impossible for a genuine object to have the predicates "is believed by A to be $\mathrm{P}$ " and "is not believed by $A$ to be $P$ " true of it, there would be no possible object to serve as the value of a variable of quantification. I can therefore only interpret this objection of Quine's to be rooted in the view that predicates must be interpreted in the same way, regardless of whether contexts are transparent or opaque.

I have already argued, however, that predicates for opaque contexts should be constructed differently. Just because no simple relation exists between the individuals described in opaque sentences, we need not conclude that no relation between individuals exists at all. We can instead say that a complex relation between $A$ and the object that $A$ believes to be $P$ holds under A's meaning for the term used to denote this object. But the fact that my view conflicts with Quine's is hardly favorable evidence. I shall

11 Cf. ibid., p. 147; also see Quine's "Reference and Modality", From a Logical Point of View, 2nd ed., revised (New York and Evanston, 1963), pp. 144-148. 
therefore state the reasons why Quine's view is unsatisfactory.

To agree with Quine that we must construe belief sentences transparently before quantifying into them would force us to trivialize sentences whose ordinay purport is not trivial at all. For example, suppose that Holmes has just discovered that someone has murdered a certain banker, although he does not yet know the murderer's identity. It is then uninformative to say, "Holmes believes that the murderer killed the banker." Heeding Quine's restriction that this trivial sentence be construed transparently, our quantifying into it yields: "There is someone such that Holmes believes that he killed the banker." Now this sentence cannot be any less trivial than the one from which it was derived. But the ordinary meaning of the quantified sentence is not trivial at all, since it is normally used only to sum up a good deal of detective work; that is, we assume in using such a sentence that Holmes has identified the murderer. The result of Quine's restriction is thus to rob a vast range of sentences like this one of their ordinary meaning. Such sentences cry out for an opaque interpretation, but Quine's strictures will not permit it. Another unhappy result quickly follows. The claim that quantified opaque sentences are nonsense reflects on unquatified opaque sentences as well. If we take seriously Quine's dictum that to be is to be the value of bound variable, it would become logically impossible to discover what a person's beliefs are about in opaque contexts. Yet surely we think that we can discover this. Quine's worries about quantifying into opaque contexts must therefore be allayed once and for all.

\section{VI}

Quine's official objection to combining quantification with opacity seems rooted in his belief that we would have to admit of individuals with contradictory predicates true 
of them. Giving a different interpretation to our predicates in opaque contexts is enough to counter this objection. Yet just to show that no contradictory predicates are involved is still not sufficient to justify quantification into opaque contexts. There remains the separate problem concerning what I shall call "strictly verbal" beliefs. These are cases in which it is best to say that one's belief concerns no object at all, but only a form of words. When a person's belief is strictly verbal, then, even when there exists an object that answers to the description under which the belief is held, this object will still not be definite enough to quantify over. As an example of a strictly verbal belief we might consider:

(11) Jones believes that the next President will expand his cabinet.

Even if we assume the existence of the individual who will in fact be the next President, we are not yet allowed to say that there is someone such that Jones believes that he will expand his cabinet; for Jones may have no inkling of who the next President will be. He may just believe what he does of anything answering to that description. To introduce quantification in the presence of such ignorance, we must be careful that it is done with but a narrow scope for the quantifier, as in the following way.

(12) Jones believes that some $x$ is such that $x$ is the next President and $x$ will expand his cabinet.

In (12), however, we do not have quantification into an opaque context, since the belief operator, not the quantifier, has the wider scope. Quine has no quarrel with this way of combining opacity with quantification, but this is because (12) fails to express a belief about a definite object.

In denying that sentences like (11) automatically permit one to. quantify into them I am not going back on my 
earlier claim that there can be a relation between Jones and the individual who is in fact the next President. There mere existence of this individual is enough to secure that relation. But the relation so secured is only a "blind" relation. It holds, so to speak, where Jones cannot see it. It is like the relation in which $I$ stand to $m y$ recluse neighbour, whom I have never seen, simply because she lives next door. ${ }^{12}$

This further problem of quantification into opaque contexts can now properly be described in terms of what one's belief is about. Faced only with a sentence like (11), we yet have no warrant to say that Jones has a belief about any definite individual. Jones's belief might be strictly verbal an not be about the next President at all. What is needed in order to quantify into an opaque sentence is a criterion for a person's belief to be about an object rather than just to hold of anything that happens to answer to a verbal description.

Jaakko Hintikka has suggested a solution to this problem by claiming that if we could say who this individual is, then this would suffice for our quantifying into an opaque context. ${ }^{\text {as }}$ In order to give sense to a sentence like "Someone is such that Jones believes that he will expand his cabinet" it must also be true to say, "Someone is such that Jones believes that he is the next President." In general, Hintikka's solution would allow us to derive from any sentence of the form "A believes that $O$ is $P$ " the quatified sentence "Some $x$ is such that A believes that $x$ is $P$ " if we have the additional premise "Some $\mathrm{x}$ is such that $\mathrm{A}$ believes $x$ to be O." In brief, we are only permitted to quantify into an opaque sentence when we already have on hand an opaque sentence into which we have quantified.

12 I get the notion of a "blind" relation from A. N. Prior, "Oratio Oblicua", Proceedings of the Aristotelian Society, Supplementary Volume (1963), p. 123.

13 Jaakko Hintikka, Knowledge and Belief: An Introduction to the Logic of the Two Notions (Ithaca, N. Y., 1962), p. 149. 
Although I think that Hintikka has provided the proper formalism, he has not paid much attention to what lies behind the question, "Who is this individual?" Nor has he fully explained what lies behind the answer. I construe the question to be a request for identification of the individual concerned, and so I take the answer to embody such an identification. It is therefore appropriate to call the condition needed to turn a "blind" relation into a belief about an object, thereby permitting quantification into an opaque belief sentence, an identification condition. To further grasp what is involved here, let us image a Quinean skeptic who asks further questions with respect to this identification condition itself. That is, if the identification condition is to be met by the statement "Someone is such that Jones believes him to be the next President," the skeptic's question would be, "But just who is this individual whom Jones believes to be the next President?" The point of the question is simply that if every quantification into an opaque context is suspect, then no such quantification will have the necessary credentials to fulfill the identification condition.

The natural answer to the skeptical question, however, would seem to involve saying that this individual has certain features uniquely true of him. If we assume that Jones believes that Edward Kennedy is to be the next President, these features would enable Jones to individuate Edward Kennedy; let us say that included among such features are being the junior senator from Massachusetts, and being the only living brother of a former Democratic president. Armed with descriptions of these features, Jones will be able to pick out whom he believes to be the next President from other individuals. Suppose we then answer the skeptic's question by saying that the individual believed by Jones to be the next President is the individual to whom these identifiyng descriptions apply.

Quine has foreseen such an answer to his challenge. His 
charge is now that if we give sense to the sentence "There is someone such that Jones believes him to be the next President" by listing characteristics whereby Jones can identify this individual, then we are landed in "Aristotelian essentialism." Individuals must now be said to possess some properties accidentally, and others essentially; and it is only through the recognition of essential properties that Jones can be assured of picking this individual out from among others. $^{14}$

I propose that we overrule this objection of Quine's in the following way. Let us grant that in order for a sentence of the form "There is some $x$ such that $A$ believes $x$ to be $O$ " to be true, some of O's characteristics must enable A to pick him out as being $\mathrm{O}$ instead of someone else. But it does not follow that the same set of characteristics are always to be used by $A$ to identify $O$. What is at issue here is therefore not some one set of essential properties, but a condition to be satisfied before allowing quantification into an opaque context. The identification condition should thus be construed as being logically independent of any particular descriptions of identifying features. All that is required is that there be some definite description or other that $A$ can use to support the identification claim that he makes.

With respect to a similar example concerned with knowing who someone is, Hintikka has remarked, "The criteria as to when one may be said to know who this or than man is are highly variable." ${ }^{13}$ To expand on this remark it should be added that identification depends upon context. What characteristics are suitable for mentioning depends

${ }^{14}$ Quine makes the connection between essentialism and identification in his reply to Sellars, in D. Davidson and J. Hintikka (eds.), Words and $O b$ jections (Dordrecht, Holland, 1969), p. 340, where he says: "What to count as essential specifications would depend on whether one is concerned with necessity or with belief. For belief one requirement would be vaguely speaking, that the specification hinges on traits by which the object in question is known to Jones." See also Quine's "Reference and Modality", pp. 155-156.

15 Hintikka, loc. cit. 
on the situation in which the question, "Who is this individual?" arises. Different situations require different answers and therefore require the mention of different identifying descriptions. So we should inform the Quinean skeptic that what counts as an identifying description is relative to the situation in which the identification is being sought. Since identification is always context-bound, there comes a time when reiteration of the question, "And who is this individual?" no longer has any point. If serious, such a question must have a purpose, and the proper answer must be responsive to this purpose. Above all, questioner and respondent must agree upon what is to count as an adequate answer in those circumstances. So any search for special identifying descriptions that would suffice for all contexts and for all people is bound to be futile. Hence, Quine's charge of essentialism is refuted by insisting that identification always proceeds in relation to the context in which individuals are specified.

There may still seem to be some disparity between the requirements for quantifying into opaque belief sentences and those for quantifying into sentences expressing other propositional attitudes. For example, consider the following opaque sentence:

(13) Richard wishes that Fidel were dead.

What would we require to derive from (13) the following quantified sentence?

(14) Some $\mathrm{x}$ is such that Richard wishes that $\mathrm{x}$ were dead.

On the analogue for belief, what we seem to require in order to derive (14) from (13) is this:

(15) Some $x$ is such that Richard wishes that $x$ were Fidel. 
But this is surely wrong. Wishing the death of a particular person does not require wishing someone else to be that person.

The threat of discrepancy here, however, is only a logical illusion which is dispelled once we remember that what must be satisfied before we quantify into opaque contexts is an identification condition. What we need to derive (14) from (13) is not (15) but the following:

(16) Some $\mathrm{x}$ is such that Richard believes $\mathrm{x}$ to be Fidel.

The reason why (16) suffices for the derivation is that to assert (16) presupposes that Richard can identify Fidel, whereas to assert (15) does not. I therefore suggest that quantification into any opaque context can be effected if we have on hand a quantified belief sentence of the form "Some $\mathrm{x}$ is believed by A to be 0. ." The reason why belief sentences of this form suffice for permitting quantification into opaque contexts expressing other attitudes is that such belief sentences seem to satisfy the weakest possible identification condition. In order for one to be of any attitude about a definite object, one must at least have a certain belief about it.

VII

One remaining problem for my contextual account of identification is that it does not seem to exclude "story-relative" identifications as being responsive to the question, "Who is this individual?" We can imagine a situation in which a listener's interest in an individual goes no further than to the role it is given in someone's story. Can we say that this listener, armed with only a story-relative indentification, qualifies as having a belief about an individual? We could of course stipulate that no set of such story-relative descriptions ever suffices to answer the question of who an individual is. But this stipulation seems to harsh. It would prohibit us from identifying historical personages. Our 
knowledge of historical figures is gained exclusively from written records, and so is essentially story-relative. Yet surely if one's knowledge of such an historical figure is extensive, and if one is asked who this person was, there seems to be no good reason why one's answer cannot be taken to constitute an identification of an individual.

Story-relative identifications therefore sometimes do seem to provide an appropriate answer to the question, "Who is this individual?" What we must do, however, is to distinguish between an identification of an individual, through someone's story about him, and the mere identification of a recurring term in someone's story. To have beliefs which are based merely upon the identification of a term in a story depends only upon being able to follow the story. To have a belief based upon the story-relative identification of an individual requires more. To have the latter sort of belief one must be able to fit the individual spoken about into one's factual picture of the world. ${ }^{16}$ Such accurate fitting usually requires a further ability to track down the object of one's belief, and this may ultimately require the existence of some demonstrative relation, either the perception of the object itself or the perception of other objects to which the former is causally tied. Such meticulous tracing of the object, however, need not even be contemplated in all cases in which it is proper to say that the identification condition has been satisfied. What makes it proper to say that we have identified an object, rather than just a term in a story, is that we are correct in our assumption that such tracing can be carried out.

Beliefs which depend merely upon identifying a term with relation to someone's story allow for no such further tracing of the object. So no identification of an individual can really be said to have occurred at all. This is the crucial difference between types of story-relative identification. Beliefs which depend merely upon the identification of

16 Cf. P. F. Strawson, Individuals (London, 1959), p. 24. 
terms in stories are among those which I have already described as being strictly verbal beliefs. In general, any belief whose sole support is story-relative, and thus which does not permit one to fit an object into one's view of the world, turns out to be stricly verbal. This applies to vague narratives as well as to fairy tales. Strictly verbal beliefs are not about objects. So quantification into sentences expressing such beliefs is prohibited, even when there exists such an object, because the identification condition for having a belief about an object has not been met.

In summary, there are two distinct conditions to be fulfilled in order to have a belief about an object. First, there must be such an object. This satisfies the existence condition. Second, one must be able to identify the object of his belief in whatever way the circumstances require; and this fulfills the identification condition. The identification condition, as well as the existence condition, must be met in order to permit quantification into an opaque belief sentence. If only the existence condition is met there is but a blind relation between a person and the object of his belief. This relation is assured by the applicability of Leibniz's Law once appropriate predicates are introduced. If there is no object at all, then there is not even a blind relation, and identification can only be made with regard to a term within a category of discourse. Such identification would be merely story-relative, and the belief based on it would be strictly verbal. What I hope to have reinforced, however, is our common conviction that not all our beliefs are strictly verbal and that sentences expressing these beliefs do express beliefs that people have about objects. 


\section{RESUMEN}

Las oraciones que expresan creencias proporcionan un modelo para el tratamiento de los contextos opacos. Se dice que una oración $S$ es opaca si, al substituir un término t' por un término $t$, en la oración $\mathrm{S}, \mathrm{y}$ ambos términos se aplican al mismo objeto, la ora. ción $S$ ' resultante, puede tener un valor de verdad diferente. De esta forma las oraciones de creencia pertenecen a la clase más amplia de las oraciones opacas. También aquellas oraciones en las que verbos como "desear", "saber", "percibir", preceden a cláusulas proporcionales, pueden dar origen a contextos opacos. En lo que sigue se desarrollarán una serie de soluciones para dificulta. des tipicas en las oraciones de creencia opacas y se sostendrá que este procedimiento puede generalizarse al resto de estas oraciones.

La substitución de expresiones en contextos no opacos se apoya en el principio conocido como ley de Leibniz. Se suele considerar que en las oraciones opacas este principio deja de cumplirse. Por lo que respecta a los predicados, cuando estas expresiones aparecen en oraciones de creencia se interpretan de la misma manera que cuando ocurren en contextos no opacos. Sin embargo, si estas expresiones reciben un tratamiento diferente en el caso de las oraciones opacas, es posible conservar el principio de Leibniz. Esto se lleva a cabo de la siguiente manera: incluyendo en los predicados la mención del significado del término que designa al objeto de la creencia. De esta forma en vez de considerar que el predicado correspondiente a la oración opaca: "Arturo cree que Cicerón fue calvo", es: "Arturo cree que fue calvo", se construye el predicado: "Arturo cree que fue calvo bajo el término "Cicerón'." Con esta modificación, la manera de considerar el predicado de la oración de creencia anterior es: el predicado "Arturo cree que 'ue calvo bajo el término 'Cicerón'", es verdadero de Cicerón. Con el objeto de evitar la dificultad que se presentaría si en el lenguaje de Arturo no se tuviese la palabra "Cicerón", es necesario especificar que la creencia de Arturo se da bajo la palabra "Cicerón" del idioma español. Otra dificultad aparece cuando se destaca el hecho de que el valor de verdad de una oración de creencia no se preserva en el caso en que tanto el término que sustituye, como el término sustituido, tengan el mismo significado. Para superar este obstáculo, se usará la noción de significado parcial de una expresión. Se entiende por significado parcial de un término aquella parte de su significado total que comprende 
la persona cuya creencia se considera. Es claro entonces que dos términos pueden tener el mismo significado total, aunque sus significados parciales sean diferentes. $Y$ es precisamente esta consecuencia de la noción de significado parcial la que permitirá explicar la posibilidad de que se dé un cambio en el valor de verdad de una oración de creencia, cuando existe una sustitución de términos con el mismo significado. En esta forma, la estrategia general para el tratamiento de las oraciones opacas consiste en conservar la ley de Leibniz en estos contextos y construir predicados que incluyan la mención de significados parciales. $\mathrm{El}$ resultado principal de su aplicación es el mostrar que la opacidad no necesita destruir una relación de creencia entre una persona y el objeto de su creencia.

Aunque las oraciones de creencia pueden ser opacas, no lo son necesariamente. Es posible hallar interpretaciones transparentes de este tipo de oraciones. Quine ha criticado esta forma de considerar a las creencias, ubicándolas sólo en contextos opacos. Pero este hecho tiene la consecuencia de que la opacidad de referencia no puede combinarse con la cuantificación, porque ella requiere objetos definidos para servir como valores de las variables. Y se sabe que en los contextos opacos puede darse el caso de que el valor de una variable tuviese predicados contrarios. En la medida en que la tesis de la imposibilidad de la cuantificación en contextos opacos descansa en el argumento anterior, es posible argüir que bajo la construcción de predicados que se ha señalado anteriormente y preservando el principio de substitución en contextos no opacos, resulta discutible la posición de Quine.

Por otra parte, las oraciones opacas de creencia, por lo que toca a la determinación de que es aquello sobre lo que se cree, pueden ser meramente verbales o bien puede darse el caso que efectivamente se logre identificar el objeto acerca del cual se tienen creencias. De esta manera la cuantificación en contextos opacos sería posible a través de dos condiciones: La existencia del objeto sobre el cual se poseen creencias y la identificación de dicho objeto. 